\title{
INFLAMMATION OF INTERSTITIAL CONNECTIVE TISSUE SPACE INDUCED BY LEAD ACETATE AND AMELIORATIVE AFTERMATH OF FICUSCARICAON RAT TESTIS
}

\author{
Ayesha Asad, Shabnam Hamid*, Afnan Gul**, Noreen Anwar, Dujanah Bhatti***, Naureen Waseem*** \\ Quetta Institute of Medical Sciences, Quetta Pakistan, *Army Medical College/National Institute of Medical Sciences (NUMS) Rawalpindi Pakistan, \\ **Shalamar Medical College Lahore Pakistan, ***Holy Family Hospital, Rawalpindi Pakistan, ***Islam Medical College, Sialkot Pakistan
}

\begin{abstract}
Objective: To observe inflammation of interstitial connective tissue space caused by Lead acetate in rat testis and ameliorative after math caused by Ficuscarica.

Study Design: Laboratory based experimental study.

Place and Duration of Study: Anatomy Department, Army Medical College Rawalpindi together with NIH (National Institute of Health) Islamabad, from Mar to Nov 2017.

Methodology: Sprague Dawley male rats, 30 in quantity were chosen and 10 animals each partited into 3 groups. Treatments were given for 8 weeks, once daily. Group A was control group. Group B was treated with dosage of $30 \mathrm{mg} / \mathrm{kg}$ of Lead acetate. Group C was given dosage of $30 \mathrm{mg} / \mathrm{kg}$ of Lead acetate as well as $80 \mathrm{mg} / \mathrm{kg}$ of Ficuscarica. Twenty four hours after the concluding dose, animals were vivisected. For histological study, testis were fixed and stained with Haematoxylin and eosin. Interstitial connective tissue space thickness was morphometrically and assessed by SPSS version 22 . A $p$-value $<0.05$ was considered significant in results.

Results: Interstitial space thickness was significantly increased due to inflammation ( $>3$ times normal) in group B in comparison to groups $\mathrm{A}$ and $\mathrm{C}$. Thickness of space was slightly increased (<2 times normal) in group C in comparison to groups $\mathrm{A}$ due to reduction in inflammation.

Conclusion: There was increased thickness of interstitium due to inflammation, cellular congestion and lymphocytic infiltration in rat's testis because of lead acetate but concomitant dose of Ficuscarica protects against inflammation, venous congestion of interstitial space.
\end{abstract}

Keywords: Ficuscarica, Inflammation, Interstitial connective tissue space, Lead acetate.

\footnotetext{
This is an Open Access article distributed under the terms of the Creative Commons Attribution License (https://creativecommons.org/licenses/by-nc/4.0/), which permits unrestricted use, distribution, and reproduction in any medium, provided the original work is properly cited.
}

\section{INTRODUCTION}

In modern world, metals are part and parcel of day to day routine. One of the post transitional metal is lead. Lead is flexible, with elevated density and decreased melting point ${ }^{1}$. Due to easy availability and being cheap, lead is widely used in daily use products such as; toy batteries, paints, construction, and varnishes. To make the lipstick holding on lips for longer durations; lipsticks have higher lead content which is six times greater than authorized by Food and Drug Administration ${ }^{2}$. Lead is the much largely prepensed vocational and natural pollutant. Lead has been precarious, for last 6000 years. Lead exposure to humans occurs via water, air and food ${ }^{3}$.

Greatly increased circulation of lead is due to worldwide lead spoliation due to human activities ${ }^{4}$. Lead exposure is dangerous for health of humans as it interferes with biochemical processes. Abundant workplace exposure of lead in workers have been found to have higher level of lead concentration in the blood 5 . Females and males are uniformly affected by lead ${ }^{6}$.

Correspondence: Dr Ayesha Asad, House No 340 A, Street No 16, Chaklala Scheme 3, Rawalpindi Pakistan

Received: 18 Dec 2019; revised received: 19 Mar 2020; accepted: 21 Apr 2020
According to NISOH-National Institute of Occupational Safety and Health, 3 million employees are divulged to lead poisoning7. The amount and time of lead exposure afflicts cardiovascular system, reproductive system, kidney and central nervous system ${ }^{5}$.

Within metals, lead is noted cause of reproductive toxicity. Structure and function of reproductive organs can be changed by lead poisoning, leading to changes in fertility ${ }^{8}$. Adverse after math caused by Lead acetate in adult male rats caused reduction in testicular weight, spermatogenic and Leydig cells showed degeneration and noxiousness and no signs of spermatogenesis at large doses along with inflammation of interstitium.

Vegetables, fruits and nuts have been known for a long time to improve health of human beings. Oxidative chain reactions that are constantly occurring in human body can be broken down by antioxidants. Ficuscarica, Fc (common fig) is widely used. Fig is a part offamily Moraceae. Fig constitutes the biggest genera of herbal medicines ${ }^{9}$. Fig is abundant in copper, magnesium, fiberand otherminerals. Fig is one of the largest sources of antioxidants. Infertility in humans can be cured by fig, as it has antioxidant properties. 
High levels of polyphenols, flavonoids, bioactive compounds like arabinose, carotenes, xanthotoxolare the plausible strength-bolstering components of Ficuscarica.

Fig has numerous medicinal properties. Fig raised the plasma antioxidant levels and is used as a haemostatic, anti-inflammatoryand anti-helminthic agent. Fig causes reduction in blood glucose and blood cholesterol levels. Fig also fights against cancer. Fig aggrandized in sperm count \& sperm numbers by suppressing ROS production.

The testes are paired ovoid organs that reside within scrotum. Average testicular dimensions are 3-4 $\mathrm{cm}$ in length, 2-2.5 $\mathrm{cm}$ in breadth and $2-3 \mathrm{~cm}$ in anteroposterior diameter. A single lobule of testes has 1-4 seminiferous tubules, where production of sperms takes place. The tissue between the seminiferous tubules is the interstitial connective tissue space ${ }^{10}$.

The objective of the research was to evaluatethe inflammation of interstitium by Lead acetate in testis of adult rats and probable fruitfulaftermath of Ficuscarica.

The rationale of my study was to evaluate the fruitful effects of fig on organs, whose anatomy is disrupted by noxious metals in the environment.

\section{METHODOLOGY}

The research was a laboratory based experimental study, IERB approval number ERC/MS-17/Anatomy, of the AMC Rawalpindi. This research was conducted in the Department of Anatomy, Army Medical College, jointly with Armed Force Institute of Pathology (AFIP) Rawalpindi and NIH - National Institute of Health (NIH), Islamabad. Male adult Sprague Dawley healthy rats, 30 in number were taken. Age of the rats was between 9-11 weeks; rats weighing 200-250gms were used for this practical, $20-26^{\circ} \mathrm{C}$ temperature was maintained for rats and they were put in a well-ventilated room. Twelve hour night-day sleeping cycle was maintained during the whole time of practical ${ }^{11}$. Standard laboratory diet was given to rats arranged by NIH. Rats were given water ad libitum. The drug and fig were given via oral gavage needle day to day for 8 weeks.

Rats in group A served as untreated controls. Group B rats were treated with Lead acetate $30 \mathrm{mg} /$ $\mathrm{kg} /$ day $^{12}$ whereas group $C$ rats were treated with $30 \mathrm{mg} / \mathrm{kg} /$ day Lead acetate and $80 \mathrm{mg} / \mathrm{kg} /$ day Ficuscarica $^{13}$. On reaching term of experiment i.e. 8 weeks, the animals were vivisected and right specimens of testis were removed. Testes wereput in formalin with a concentration of $10 \%$, in duly labeled separate plastic containers. The coronal section of each right testis was taken. Before embedding, it was ensured that the sections were oriented perpendicular to their long axes. Specimens were put in duly labeled tissue tek cassettes and processed in Leica TP 1020 automatic tissue processor. Sections were processed through the increasing concentration of alcohol from $70-100 \%$, cleared in xylene. Paraffin wax with melting point $58^{\circ} \mathrm{C}$ was used for infiltration and embedding. For this purpose, paraffin embedding center LEICA EG 1160 was used. The blocks were allowed to solidify on a cold plate and then in a rotary microtome 5-micron thick sections were made. H\&E - Haematoxylin and eosinstain was brought touse for staining the sections, this stain is used to view histological slides of testis in a light microscope. Right testes of 30 animals were observed. One section per animal was observed. Total 30 interstitial spaces were observed in each group. From each section one tubule was chosen and interstitial connective tissue space thickness was estimated by calculating 3 distances of one interstitial space from one seminiferous tubule's basement membrane to the surrounding seminiferous tubule basement membrane ${ }^{14}$. An objective micrometer with 40X magnification was used to measure the interstitial space in each testes section. Digital camera by Olympus (12-mega pixel) was used to take pictures of section from each slide. The images were then transferred to laptop. Image J v1.4815 was used to open each image. To calculate the thickness in micrometer, a scale was set at 40X. 'Straight' tool was chosen for calculation and the thickness to be calculated was measured by making a straight line. The mean of the 3 distances was taken and average mean was calculated to attain the thickness in whole of the interstitial space for every Haematoxylin \& Eosin stained section ${ }^{14}$. Statistics were evaluated with the help of statistical package for social sciences version 22 . The thickness of the space was articulated as mean \pm standard deviation. Difference was found out with the help of one way analysis of variance (ANOVA) and after that post Hoc Tukey test was applied. Significant $p$-value was taken as $<0.05$.

\section{RESULTS}

Thirty Sprague Dawley, male adult rats; whose age was between 9-11 weeks, were taken for this research. The average weight of rats was $300 \pm 2.7 \mathrm{gm}$.

The histology of the slides showed that Experimental group $\mathrm{C}$ and control group A displayed regular architectonic with closely arranged, oval or 
semi-round seminiferous tubules (fig-1A \& C). Group $B$ showed pronounced changes with small diffuse seminiferous tubules and wide connective tissue space of interstitium due to inflammation, because of the hypoplasia of seminiferous tubules (fig-1B). Mean thickness \pm SD of connective tissue space of interstitiumin Control group A was $111.43 \pm 5.03(\mu \mathrm{m})$, it was eminently statistically significant in comparison to experimental group B and C ( $p$-value $\leq 0.01)$ Mean thickness \pm SD of interstitial space of experimental groups B and C were $140.92 \pm 3.42(\mu \mathrm{m})$ and $125.53 \pm 3.59(\mu \mathrm{m})$ respectively (table-I, fig-2) (given at end of document, after the references). While doing comparison within the groups, increase statistical significance was showed by group B ( $p$-value $\leq 0.01$ ) with groups C (tableII) (given at end of document, after the references).

\section{DISCUSSION}

Lead acetate exposure is the leading health risk with universal magnitude ${ }^{16}$. Lead altersthe functioning of various vital body organs. There are cellular, structural and biological effects in humans caused by lead

Table-I: Comparison of mean value of thickness of interstitial connective tissue space within control group A and experimental groups $B$ and $C$.

\begin{tabular}{|c|c|c|c|}
\hline 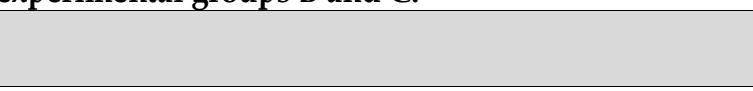 & $\begin{array}{c}\text { Group A } \\
\text { Mean } \pm \text { SD }\end{array}$ & $\begin{array}{c}\text { Group B } \\
\text { Mean } \pm \text { SD }\end{array}$ & $\begin{array}{c}\text { Group C } \\
\text { Mean } \pm \text { SD }\end{array}$ \\
\hline Thickness of interstitial connective tissue space $(\mu \mathrm{m})$ & $111.43 \pm 5.03$ & $140.92 \pm 3.42$ & $125.53 \pm 3.59$ \\
\hline
\end{tabular}

Table-II: Comparison of $p$-values of thickness of interstitial connective tissue space among control group $\mathrm{A}$ and experimental groups $B$ and $C$.

\begin{tabular}{l|c|c|c}
\hline & Group A vs. B & Group A vs. C & Group B vs. C \\
\hline Thickness of interstitial connective tissue space & $0.000^{*}$ & $0.000^{*}$ & $0.000^{*}$ \\
\hline
\end{tabular}

p-value $\leq 0.05$ is statistically significant, ${ }^{*}$ Highly significant

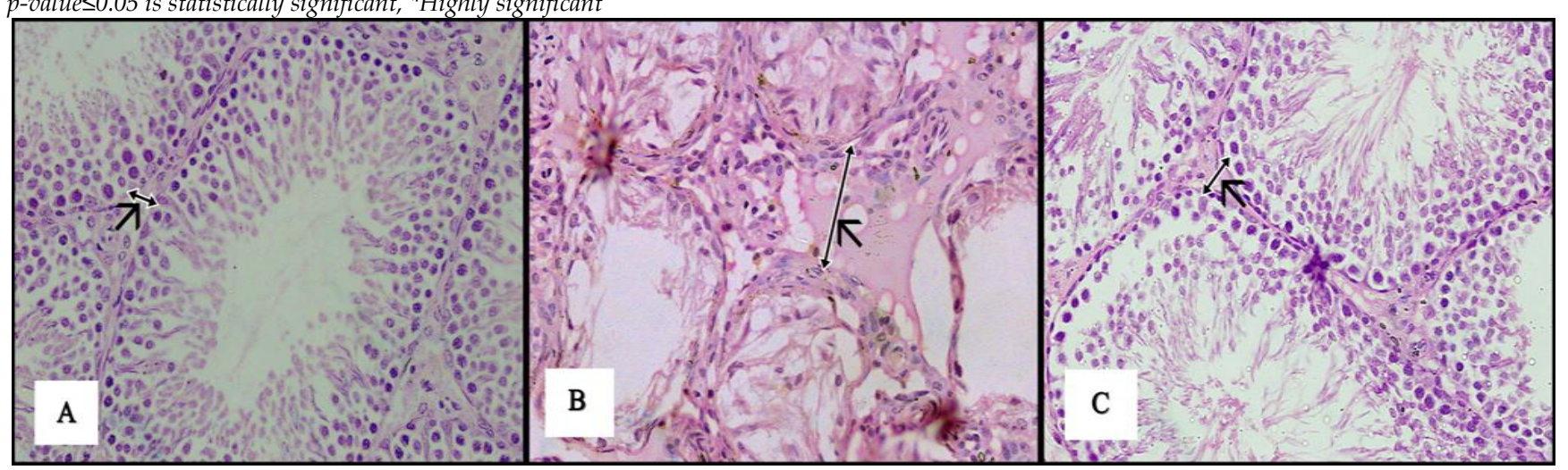

Figure-1: Photomicrograph depicting comparison of interstitial connective tissue space. (A) Measurement of interstitial connective tissue space thickness (Arrow) in control group A, (B) Increased interstitial connective tissue space due to inflammation (Arrow) in experimental group B, (C) Decreased interstitial connective tissue space (Arrow) in experimental group C as compared to group B: $40 \mathrm{X}, \mathrm{H} \& \mathrm{E}$.

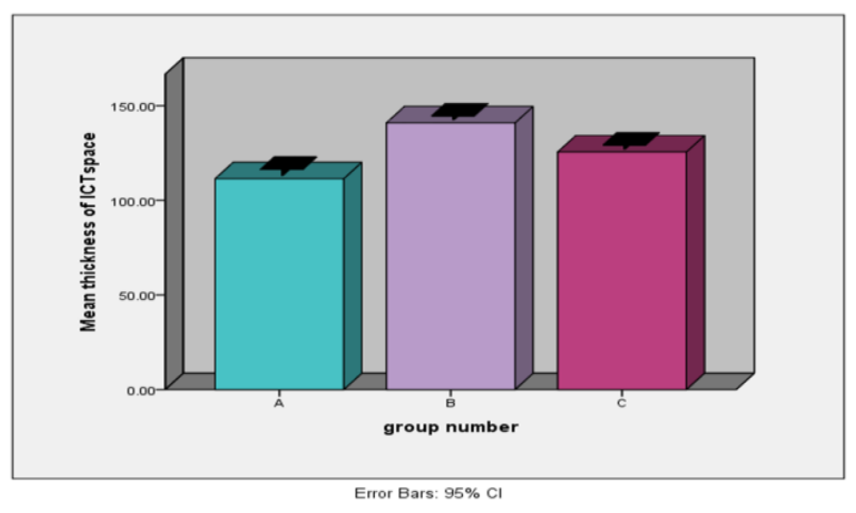

Figure-2: Comparison of mean values of thickness of interstitial connective tissue space among the control group $\mathrm{A}$ and experimental group $B$ \& $C$. leading to extensive destruction ${ }^{17}$. Ficuscarica is extensively consumed raisin with numerous antioxidants. The antioxidants in figs stop the oxidative mechanisms causing destruction at cellular level ${ }^{18}$. The nutrients amalgam of dried Ficuscaricatells that it is the best dry frit to consume, having a variety of vitamins, antioxidants and minerals ${ }^{19}$. This research was devised to inspect Lead acetate effects on the testis of adult rats and investigate simultaneous dispensation of Ficuscarica, and its aftermath.

In this current study, histological slides of testes were studied under microscope for interstitial connective tissue space thickness. Vulnerability to clement dosage of lead acetate amends the testis architectonic with escalation in thickness of connective tissue space 
of interstitium due to inflammation. In control group A the interstitial thickness remained in normal limits. We saw an escalation in the thickness of connective tissue space of interstitium because of the inflammation, there were also with distended blood capillaries in the experimental group B in comparison to control group A. This increase in thickness was highly statistically significant with $p$-value of $<0.01$. The same conclusion was obtained by another study conducted in 2017 by Ahmed et al, that significant inflammation is seen in interstitial connective tissue space when noxious metal was administered ${ }^{14}$. A similar study was conducted in 2018 by Najat et al, who found out that interstitial connective tissue space was increased when excessive hormones were administered ${ }^{20}$. One more study done in 2018 by Sudjarwo et al, establishes that lead acetate has deleterious effects on male reproductive system, causing distortion of seminiferous tubules and low sperm count ${ }^{21}$. The apprehension for escalation in interstitial connective tissue space thickness was due to the inflammation of interstitium, atrophy of seminiferous tubules, decrease in number of the Leydig cells and intertubular connective tissue space with lymphocytic infiltration and congestion of blood vessels ${ }^{22}$.

The interstitial connective tissue space in experimental group $\mathrm{C}$ was nigh to control group $\mathrm{A}$ and the $p$ value was found highly statistically significant ( $p$-value $\leq 0.01$ ). Interstitial cells, basement membrane and seminiferous tubules have alkaline phosphatase in them; its deficiency leads to hypoplasia of interstitial connective tissue space ${ }^{23}$. Ficuscarica is gilded in xanthins, phytosterols and antioxidants. Figs by decreasing lipid peroxidation, restores alkaline phosphatase. A study conducted in 2017 by Hardey et al, supports the beneficial effects of Ficuscarica on rat testis stating that it helped in reversing the poisonous effects and reverted the seminiferous tubules histology to nearly normal with healthy spermatozoa ${ }^{24}$. Hence exerting a shielding effect on rat testis against lead acetate poisoning.

\section{ACKNOWLEGMENT}

I am greatly indebted to all the faculty of the Anatomy department, Army Medical College, Rawalpindi.

\section{Disclosure}

All the contributors of the article were serving at Army Medical College when the research took place.

\section{CONCLUSION}

Our research suggests that escalation in thickness of connective tissue space of interstitium was due to inflammation, lymphocytic infiltration and cellular congestion in testis of adult rats, which was caused by lead acetate and Ficuscarica simultaneouslyfed will have defensive after math on the interstitium.

\section{CONFLICT OF INTEREST}

This study has no conflict of interest to be declared by any author.

\section{REFERENCES}

1. Sobolev V. Thermophysical properties of lead and lead-bismuth eutectic. J Nucl Mater 2007; 362(2-3): 235-47.

2. Pastoril MFM, Seno VCA, Gingoyon KD, Cuevas GPR. Variation analysis of the top 100 high lead content lipstick brands. Uni Visayas J Res 2015; 9(1): 75-80.

3. Sajitha G, Jose R, Andrews A, Ajantha K, Augustine P, Augusti K. Garlic oil and vitamin E prevent the adverse effects of lead acetate and ethanol separately as well as in combination in the drinking water of rats. Indian J Clin Biochem 2010; 25(3): 280-88.

4. Tong S, Schirnding YEv, Prapamontol T. Environmental lead exposure: a public health problem of global dimensions. Bull World Health Organ 2000; 78(9): 1068-77.

5. Mahurpawar M. Effects of heavy metals on human health. Int J Res Granthaalayah 2015; 530: 1-7.

6. Winder C. Lead, reproduction and development. Neurotoxicol 1993; 14(2-3): 303-17.

7. Staudinger KC, Roth VS. Occupational lead poisoning. Am Fam Physician 1998; 57(4): 719-26.

8. Qureshi N, Sharma R. Lead toxicity and infertility in female Swiss mice: a review. J Chem Biol Physical Sci 2012; 2(4): 1849.

9. Jasmine R, Manikandan K, Karthikeyan K. Evaluating the antioxidant and anticancer property of Ficus carica fruits. Afr J Biotechnol 2015; 14(7): 634-41.

10. Ross MH, Pawlina W. Histology: Lippincott Williams \& Wilkins; 2006.

11. Hessler J, Lehner N. Planning and designing research animal facilities: Academic Press; 2011.

12. Elgawish RAR, Abdelrazek HM. Effects of lead acetate on testicular function and caspase- 3 expression with respect to the protective effect of cinnamon in albino rats. Toxicol Rep 2014; 1(1): 795-801.

13. El-Shobaki F, El-Bahay A, Esmail R, El-Megeid AA. Effect of figs fruit (Ficus carica L.) and its leaves on hyperglycemia in alloxan diabetic rats. World J Dairy Food Sci 2010; 5(1): 47-57.

14. Ahmed S, Ali T, Elsheikh A, Attia G, Abdalla A. Testicular changes in male albino rat pups exposed to medroxy-progesterone acetate during lactational period. J Steroids Horm Sci 2017; $8(184): 2$.

15. Schneider CA, Rasband WS, Eliceiri KW. NIH Image to Image J: 25 years of image analysis. Nature Meth 2012; 9(7): 671-75.

16. Borghini A, Gianicolo EA. Usefulness of biomarkers as intermediate endpoints in health risks posed by occupational lead exposure. Intl J Occup Med Environ Health 2016; 29(2): 167.

17. El-Tantawy WH. Antioxidant effects of Spirulina supplement against lead acetate-induced hepatic injury in rats. J Traditional Complement Med 2016; 6(4): 327-31.

18. Joseph B, Raj SJ. Pharmacognostic and phytochemical properties of Ficus carica Linn-An overview. Intl J Pharmtech Res 2011; 3(1): 8-12.

19. Zubair R, Baig A, Aliyu I. Non-toxic antiproliferative effect of Ficus carica fruit extracts on estrogen receptor positive breast cancer cell (MCF-7). J Chem Pharma Res 2015; 7(10): 815-21. 
20. Mohammad NA, Al-Bakri N, Selman MO. The effects of progesterone on mice offspring testis development and anogenital distance postnatally. Iraq J Embryos Infert Res 2018; 8(1): 46-54.

21. Sudjarwo SA, Sudjarwo KGW. Protective effect of curcumin on lead acetate-induced testicular toxicity in Wistar rats. Res Pharma Sci 2017; 12(5): 381.

22. Khayyat LI. The histopathological effects of an electromagnetic field on the kidney and testis of mice. Eur Asia J Bio Sci 2011; 5: 103-09.
23. Liu Z, Sun $Y$, Su L, Sun $Y$, Kong S, Chang X, et al. Effects of cisplatin on testicular enzymes and Sertoli cell function in rats. Fundamental Toxicol Sci 2015; 2(4): 137-45.

24. Haredy SA, Imam TS, Ahmed-Farid OA. Combination of ficus carica leaves extract and ubiquinone in a chronic model of lithium induce reproductive toxicity in rats: Hindrance of oxidative stress and apoptotic marker of sperm cell degradation. J Pharm Biolog Sci 2017; 12: 64-73. 